\title{
COURTING INNOVATIVE DIPLOMACY FOR HEALTH SAFETY AND SECURITY AMIDST THE COVID-19 PANDEMIC; THE CASE OF SOUTH AFRICA
}

\author{
Toyin Cotties Adetiba \\ Department of Political and International Studies \\ University of Zululand, South Africa \\ 1 Main Road, Vulindlela, KwaDlangezwa, 3886 \\ AdetibaT@unizulu.ac.za,oluwatoyin9ja_333@outlook.com
}

\begin{abstract}
Notwithstanding its level of socio-economic development, health failure is a threat to any country. Globally, the Covid-19 pandemic is believed to be the greatest threat to the existentiality of humanity since the end of World War II. The level of global interconnectivity also made it the most destructive to human existence. The accelerating growth of the pandemic in South Africa has devastated effects on its economy and cuttingly intensified prior socio-economic challenges and inadvertently, presented South Africa with an unseen and formidable enemy that does not know the differences between South African Black, Coloured, Indian or White. The study used a qualitative research approach, underpinned by the rationality for South Africa, to embrace innovative diplomacy as a means to an end for its health safety and security amidst the Covid-19 pandemic. The paper argued that South Africa must innovatively engage the acceptable global mechanisms and other health security measures with focus on its commitment to the goals of its national interests, while strengthening the efficiency of its health initiatives through better-quality governance where both local and international investors are allowed to participate actively in state socio-economic activities that respond to the safety and health security of the emotionalized publics. Thus, in a globalised system of innovation, South Africa needs to see the innovation environment as a steady pipeline of its domestic ability to control the negative effect of Covid-19 on its national health security. The paper concludes that South Africa must begin to invest, modify, and localise the biotechnology industry, and thus serving as a source of employment for the teaming unemployed South Africans.
\end{abstract}

Keywords: South Africa, Covid-19, diplomacy, innovation, development, multiracial, democratic, negotiation, technology.

DOI: $10.21303 / 2504-5571.2021 .002068$

\section{Introduction}

Significantly, every country notwithstanding its level of socio-economic development would be threatened by public health failure. Regardless of its origin, large-scale health emergencies usually have sweeping consequences that transcend national boundaries on states' health security. Thus, the outbreak of viruses can emerge anywhere and spread rapidly as a result of global interconnectivities and soon escalate expeditiously into regional or into a global pandemic. Such is Covid-19, which have resulted into global loss of life, social disorderliness, disruption of states' economies, while decelerating sustainable development and the same time threatening diplomatic relations.

Globally, the Covid-19 pandemic is believed to be the greatest threat to the existentiality of human race since the end of World War II. Covid-19 may not be the deadliest or most infectious disease ever recorded in human history, nonetheless the level of global interconnectivity has made it the most destructive to humanity socially, economically, and politically [1]. The depth of the global economic crisis since the beginning of 2020 is extraordinary as a result of the devastating effect of the Covid-19 on human existence; not only is the pandemic considered [by economic experts] as worse than the 2008 global economic recession, but it is worsened by its manifestation at the time when there is weakened global cooperation and political self-importance over Covid-19 internationally, with many individual states also weakened economically. Overtly, South Africa and the global community are experiencing a "new normal" socio-economic and political revolution, which might transform the way we live, work, play, organise our societies and ultimately define ourselves forever. 
The number of confirmed Covid-19 cases globally, is over 175.2 million with nearly 3.78 million deaths [2]. However, South Africa is the most affected country, in Africa with more than 2.7 million infections and over 80 thousand deaths.

South Africa, with a majority black populace, is a multiracial democratic country with a population of more than 61 million people. South Africa, though has a well-diversified and industrialized economy, but has at the same time suffered several years of low economic growth attributable to such economic factors as low prices for commodity exports, lack of trust on the part of the investors, policy uncertainty, and the rigid local labour markets [3]. However, the accelerating growth of Covid-19 in the former apartheid enclave have had a devastating effect on its economy and cuttingly intensified prior socio-economic challenges, [which include high rates of poverty, social inequality, unemployment, and public service access disparities that affects the majority blacks] facing the country. With the outbreak of Covid-19, overtly, this may further contribute to the country's low economic growth pattern.

Debatably, the Covid-19 pandemic has offered a developing economy like that of South Africa another transformational and systemic shift in its socio-economic development. While the disruptions of the international environments may seem to many like insignificant inopportuneness for a well-to-do state, the probability that they may have a devastating effect on matters of human rights in particular is significantly high [4].

Adetiba [5] comments that globally, it has become a norm for every Dick, Tom, and Harry that touching things, surfaces, shaking of hands, sneezing and breathing the air in an enclosed space can be dangerous if not a risky adventure. Thus, to forget the memories of Covid-19 completely for anyone who lived through it will be a herculean task. Obviously, having the mind-set that one could easily be infected with the virus could insentiently become a norm to withdrawal from shaking hands or touching our faces.

The outbreak of Covid-19 has inadvertently, presented the South Africa and by extension the global community with an unseen and formidable enemy that does not know the differences between South African Black, Coloured, Indian or Whites. South Africa though, is faced with other, equally pressing issues, most importantly, the restoration of its economy, and creation of jobs while trying to maintain some robust relations with the outside world during and after Covid-19 pandemic. This unarguably, requires a well-coordinated and constructive socio-economic programme to develop and maintain socio-political stability amid the continuing social and economic crisis in the country. Given the current level of tension, orchestrated by Covid-19 in the country, it is imperative that South Africa begin to promote more constructive patterns of innovative diplomacy for safety and security.

The key aim, underscoring this study, is the possibility of South Africa engaging innovative diplomacy while transforming its health safety and security environment amidst the Covid-19 pandemic. As seen above, a well-coordinated and constructive socio-economic programme can lead to the acceleration of economic development while fighting the pandemic.

\section{Materials and Methods}

This study adopted a qualitative research approach. The study relied on secondary data that were carefully drawn from related works through a systemic analysis. Using thematic content analysis which permits scholars to validate theoretical texts as well as the authors' observation of events in the study area, the study takes an all-inclusive research method to unpack innovative diplomacy vis-à-vis health safety and security in South Africa amidst the Covid-19 Pandemic.

The study was underpinned by the rationality for South Africa to court innovation as a means to an end in its health system, while gunning for its safety and security amidst the Covid-19 pandemic. This question enabled the author to reflect on the new normal socio-economic, scientific revolution, which might transform the way South Africans live, work, play, organise its societies, and ultimately define South Africa forever.

\section{Result}

\section{1. Innovative diplomacy, a theoretical concept}

Within the premise of the contemporary diplomacy, innovation can be one of great instruments for states that has the tendency to diplomatically increase awareness not only of safety and 
health security but of [their proffered] solutions to the ongoing diplomatic issues cum crises. These include diplomatic efforts by state and non-state actors to facilitate access to and usage of innovatism to solve diplomatic problem. Without much ado, every state has had to adjust and embrace the fast-changing international political environment. Granting the need for innovative diplomacy, developing states with particular reference to Africa might be faced with numerous socio-political limitations. Contrariwise, the dynamics of the need to harness innovation in diplomacy for safety and security and its challenges is a function of its influence on international relations.

With innovations in knowledge and technology, globalization has titivated the traditional ways of conceptualizing and organizing innovative diplomacy for health, safety, and socio-economic means to improve human safety. The recent rise of health as a diplomatic concern shows the commitment and agreement for global health safety and security through the involvement of diverse international actors at different levels of governance. It therefore means that globally, innovative diplomacy for health and safety can be described as a transformative discipline, having the potential to further dialogues on human rights, as well as provides a framework for understanding the innovative diplomacy for health and safety issues and their negotiation at different global governance venues to seek for the positioning of health and safety issues in diplomatic negotiations [6].

The Federal Department of Foreign Affairs, Switzerland [7, p. 3] defines diplomacy as the means, by which independent states conduct their affairs in ways to ensure peaceful relations. From the historical context of diplomacy, it is rooted in the communication between men, tribes, communities, and subsequently states. Kalvins [8] comments that the term takes its root from the $18^{\text {th }}$ century French word "diplomate" meaning him/her who was authorized by a state to lead and negotiate on its behalf. Diplomacy has also been defined as the conduct of human affairs by peaceful [diplomatic] means, where the techniques of persuasion and negotiation are engaged [8-10]. Using the weapon of negotiation, international affairs are usually managed by diplomats, thus making diplomacy an essential socio-economic and political activity, and hence a major element of [international] power that empower independent states to engaging diplomatic means to achieve the objectives as well as the targets of their foreign policies, while avoiding the employment of coercion.

It can therefore be argued, that diplomacy is a value laden instrument of international engagement that is capable of incorporating the promotion of socio-economic, scientific or cultural relations among autonomous states, while ensuring commitment of the international agreement to the defence of human rights as well as peaceful settlement of [international] disputes. Habitually, diplomacy is to a certain degree hierarchical, and somewhat secretive. O'Gorman [11, p. 6] concurred that one of the integral physiognomies of diplomacy has been the use of confidentiality or secrecy in its relations and negotiations, and it underpinned the very essence of the polities and diplomacy of states. Consequently, secrecy is an indispensable element of diplomacy [12]. Secret diplomacy can be interpreted as holding unto the secrecy of the contents of a negotiation between [two or more] states, knowledge of ongoing negotiations, the content of any [bi-lateral or multi-lateral] agreement, resulting from diplomatic negotiations, or any international agreement that has been reached [10].

An ability to avoid diplomatic errors and being diplomatically cautious about international change underpins the culture of diplomacy. In the meantime, the international community is yet to see the last of internal and international conflicts, presumably, the best and the only available tool in the hands of diplomats to reach agreements, compromises, and settlements is diplomacy [11].

Monopolising their influence on IR, to some extent has become a challenge to [state and non-state] actors in international diplomacy [13]. What account for this might be because every state goes through what Matambo [14] called "critical junctures" in IR. This is a situation of diplomatic uncertainty where the decision, taken by the state actors, is causally and very important to the selection of one diplomatic goal of institutional development over other possible diplomatic goals. Usually, these junctures are fundamentally significant in a country's diplomatic history as well as fundamentally enough to change the course of that country's diplomatic relations [with other countries]. Just as the power to change from circumventing politics, while avoiding conflict, has always been demonstrated by states as early as the 18th century, so also the power of the international scientific community has been able to transform international relationships. In line 
with Bound's argument, Griset [15] agreed that, conceptually, innovative diplomacy emerged after economic diplomacy as one of the major areas of diplomatic reflection on new global diplomatic practices.

Theoretically, innovative diplomacy should build on the combination of power in the fields of international relations, with its orientation on economic opportunities and learning that comes through innovation driven policies [16, p. 3]. Thus, science diplomacy connotes the use of the soft powers of scientific cooperation amongst states to grease their socio-economic and political relations. This is referred to as science for diplomacy [17]. Because of the scientific issues involved, science diplomacy has become a trans-national phenomenon that often encounters serious difficulties in bilateral and multilateral relations, and in diplomatic negotiations. This is because of divergence of socio-political and economic interests among states, and between states and non-state actors.

Innovative diplomacy can therefore be seen as a diplomatic channel, through which healthy diplomatic relations can be maintained in times of global tension, often triggered by challenging situations, such as global pandemic. It thus means that innovative diplomacy is a pedestal to peace that unites people of different socio-political, economic, and cultural background. Driven by science and technology, the goals [and practices] of innovative diplomacy continue to transform the international community, thus making it an important non-traditional security issue that transcend borders. Thus, with the growing importance of knowledge driven innovation, the growth in socio-economic and competitive thinking is a function of global and sustainable solutions to global needs in health security.

Debatably, separating the principles that drive innovation from economics cum health policies may be a herculean task just as innovation seems inseparable to successful diplomatic interactions. It can be argued, that innovatism depends on sustainable economic activity to provide the resources, while bringing light to the scientific problems that will enable innovation to answer the right health security questions, but of a certainty, it generates economic activity, which is why the interactions between science, which is a product of innovation, and economy constitute some multifaceted security elements when analysing global affairs. Innovative diplomacy therefore, requires a better understanding of, and cooperation between the states and global health communities to achieve effective policies.

In between two extremes of [international] political economy is diplomacy for innovation [16]. The neo-liberal theory states that fundamentally, every state [including South Africa] benefits from the means of production in developed economies, which comes through the free exchange of technical knowledge and flow of capital. Debatably, this can only be realised through multilateral and bilateral agreements, coalitions and cooperation, driven by innovative laden ideas. The other extreme dwells on short-term self-interest driven diplomatic approaches. The protection of states' national commercial interest is the focus of this approach. From the foregoing, one can say that innovative thinking is the driven factor between these two extremes. Thus, helping to identify series of innovative processes cum developments, as a guide to the development of diplomacy for health safety and security.

Fundamentally, the concept of innovative diplomacy can be one of the keys to dynamically take the link between health safety, security and extension economy into account. It thus means that innovation can be linked to the world of scientific knowledge and ideas in health safety, on the one hand, and health security on the other. By implication, innovation appears as an element in diplomacy after security and science. This can be of help to better delineate, as well as characterise, detailed diplomatic practices. Hence, the argument that the definite silhouette of science, technology and innovative diplomacy is the outcome of developments in health science [and safety], technology and innovation as the driver of positive multilateral and bilateral in international developments [16].

Scholars have always used the term innovation, while time after time referring to scientific innovations though, in a broad sense, however, innovation in many respects, can be linked with many forms of commercial, organisational, socio-cultural creativities [5]. One basic rule that has become the absolute rule in the business world according to Kahn [18] is innovate or perish. This, 
in a far and more reaching way, has become the motivating and diplomatic factor that can serve as a new impetus to opening South Africa's diplomatic borders to innovative ideas in health safety and security.

Innovatism has to some degree become conventional, particularly, in public debate where it has asserted itself as fundamental to scientific values of modern society, which could not be seen and claimed by states as fundamental to their diplomatic strategies. It thus means that innovative diplomacy has emerged as a diplomatic concept, hinged on a close observation of diplomatic practices among states [15].

To some extent innovative diplomacy is an imaginative ability of states like South Africa to adapt to future diplomatic challenges amidst global pandemics that can present itself anytime, it should be seen as a promotional tool for international partnerships while supporting the dynamism of the international health safety that underpins the appeal for a space to attract international investment in health security. Notwithstanding major diplomatic challenges, innovation can be the pedestal to building the socio-economic alliances that transcends political or cultural differences, while at global level dealing with issues, such as the Covid-19 pandemic. This is the reason while global collaborations through research in dealing with health challenges that easily threaten the existentiality of humanity is fundamental.

Within the international community, China stands out among the countries that have been highly successful while engaging innovative diplomacy. Strategically, the Chinese approach to all-encompassing international collaboration continues to increase [13]. This process was opened up in 1978 as part of Chinese foreign policy. This has been consistently used to propel the Chinese' economic development [19]. Across the globe and in particular Africa, through innovative diplomacy the Chinese influence has spread across every aspect of its socio-cultural and economic system, such that it cut across joint academic research to technology transfer and licensing, foreign direct investment, and mergers and acquisitions.

Based on the Chinese innovative diplomacy, its socio-economic system is overt and covertly connected to sources of global expertise. This is corroborated by Breznitz and Murphree [19] that the Chinese' willingness, where necessary, to buy expertise off the shelf is one of the aspects of Chinese foreign policy that disentangles its innovative diplomatic policies from others. Hence the conclusion that the Chinese consistent ability to align its diplomatic thoughts, belief, and actions with its goals on shaping global interactions to serve national innovation goals has become its great diplomatic strengths.

From the Chinese innovative experience in diplomacy, it means that the major foreign policy cum diplomatic tools that states can use, while promoting and benefiting from their foreign policy actions, is its adaptability to change and innovativeness [5]. Basically, South Africa needs to re-evaluate the relevance of its diplomatic mental maps they have relied on to make sense of its capability to explore innovative diplomacy for health safety and security, while dealing with the international community. However, very central to evaluation of South Africa' diplomatic mental maps amidst the global pandemic is questioning the relevance and adequacy of its existing diplomatic practices amidst the intricacies of the modern diplomatic environment. Therefore, South Africa has had to understand the contemporary diplomatic environment vis-à-vis the importance of innovative diplomacy for health safety and security.

Globally, what determines a nation's standing around the world and its relationships with other nations is the quality of its diplomacy. Diplomacy incorporates more than the advancement of peaceful global relations, it also applies to the sum total of relations, be it peaceful or hostile relations, as long as these relations involve the interests, direction, and actions of a state [20]. By interpretation diplomacy is the practice of setting diplomatic priorities; planning for and obliterating any eventualities in diplomatic relations; advancing strategic, operational, and tactical diplomatic aims, while observing other extraneous limitations to diplomatic moves.

Identifying global health as a pressing diplomatic issue, the foreign ministers of seven countries, including South Africa, in 2007 issued the Oslo Declaration, a reflection of decades of decline trend, in which health has become important in global policy agendas, although not the beginning of interest and the call for a healthy foreign policy on health issues [21]. 
In their submission, the foreign ministers of Brazil, France, Indonesia, Norway, Senegal, South Africa \& Thailand [22] believe that in this era of globalisation and interdependence of states, there is an urgent need for states to broaden the scope of foreign policy, which must be a pressing focus of every responsive government. Globally and in particular in the developing states, health seems to be one of the most neglected aspect contrary to the fact that investment in health is fundamental to economic growth and development. It thus means that threats to health may unsuspectingly compromise a country's health stability and security, hence the necessity is to see the need for a stronger and deliberate strategic foreign policy issue, whose focus is on health. Where new ideas that seek and develop new partnerships and mechanisms and create new paradigms of cooperation are encouraged.

The transformation of communication and access to information through technology cum speedy breakthrough in the areas of genomics, biotechnology, nanotechnology, is an indication that health is wise, there are new opportunities as well as new risks to be managed. Debatably, infectious diseases, such as avian influenza, severe acute respiratory disorder, extensively drug-resistant tuberculosis etc. has no respect for geopolitical borders and thus the relentless spread of Covid-19 across the length and breadth of the world represents a destructive threat to the entire humanity, hence the need for states to work together.

A healthy population no doubt is fundamental to inclusive development, security and stability. Contrariwise, poor health does more than damage to the economic and political viability of any country, in fact it is a threat to the socio-economic and political interests of all countries [21, p. 3].

According to Chattu, Knight, Kevany, \& Sehovic [23], the Commission on Human Security (CHS) delineates human security as the protection of all human lives from critical and pervasive threats that are vital and fundamental human existence. They went further that the rise of health as a foreign policy concern is an indication of an increase in the commitment and agreement by diverse states and non-states actors at various levels of governance to the issue of health globally.

Global Health Diplomacy (GHD) connotes a transformative discipline with the potential to further human rights dialogue; a platform for providing a framework where a better understanding of global health issues and a better comprehension of the discussions around global health issues that often takes place in different global governance venues is allowed; a paradigm shift that makes case for health issues in foreign policy deliberations [24]. GHD is a concept that is concerned with the design, selection, and delivery of global health interventions and programs in accordance with diplomatic criteria, in so doing simultaneously, advancing the health of the developing states, while contributing to a health perspective in international relations as well as nation building, and other non-health concerns and non-health security [23].

The Lancet [25] believe that the distorting of the line of institutional responsibilities to advance and protect global and international health of recent, has been shown by expanding the mandate of the military in response to such health emergencies as the west African Ebola outbreak, this was also repeated in several countries across the globe in response to the outbreak of Covid-19. In South Africa for example, the South African National Defence Force (SANDF) was deployed in several provinces of the country to enforce and maintain the lockdown rules.

This is evidence that the South African Department of Defence have moved from just protecting the health of the SANDF, from security and health threats to partnering with the Department of Health to achieve health security cooperation, while building the healthy nation. One can conclude here that the goals of such deployments are in support of the national health strategy as well as a humanitarian action. This however may not be militarily, politically, or legally neutral but diplomatically sending a message to the international community particularly, the SADC and other African states that SANDF has the capability to assist other country with a peculiar health and security challenge.

Thus, it is showing that health outcomes, access to socio-economic services, and most importantly, health for all remain the primary and the operational goals of the state. It is imperative to state, that a good and well managed health system has the diplomatic capability to strengthen non-health initiatives to the advantage and fulfilment of both the state and non-state actors' expectations, and by extension to the advantage of the global community. The argument is that health 
globally is human-centric and any danger to its security is tantamount to threatening the existentiality of the human race and its security and not necessarily a threat to state security [23].

Unarguably, international terrorism [which has defiled diplomatic and conventional hard power responses] is a threat to global health, in that a Covid-19 infected member of a terrorist organisation may decide to transmit the virus. Hence the question, what could, or should, global health does about it? Isolate, establish boundaries, and stove-pipe [26]. Or accept the possibility that consideration should be given to both health and non-health programmes design and delivery, which are both benign and inevitable under smart power - the ability of a state to combine hard and soft power into a winning strategy, where the strategic use of diplomacy persuasion, capacity building, and the projection of power and influence in ways that are cost-effective and have political and social legitimacy is prioritised.

Because health security is concerned with the well-being of the global community, irrespective of where people live, it is also concerned with all available diplomatic strategies for transformation and its improvement with collaborations from population-wide efforts, individual-based healthcare actions, as well as cross-sectional partnerships [23]. Over time, global health has become more of an interdisciplinary field, where studies on health have been linked to international trade, intellectual property rights, agriculture, education, and the environment.

The contemporary global health environment builds on over one hundred and fifty years of health history, where structures to promote health and fight diseases across geopolitical boundaries were established, broken down into five historical periods; The first International Sanitary Conferences (1839-1900), the first International Health Organizations (1900-1950), the creation of WHO (1948-1977), the Alma-Ata Declaration on Primary Health Care for All (1978-2000), and the Millennium Development Goals [16, 27-29], hence the increased interest in the discussion of health diplomacy globally.

Kickbusch [27] in his observation believes that there is an interaction between health and diplomacy that differently interrelates as determined by the situation on the ground. Therefore, the interests and interactions of a country can advance health diplomacy at a specific moment, which in other conditions, may become an instrument of foreign policy [23], meaning that a common theme of national interests can be served but with a different diplomatic influence and relationship with health, which they defined in four fields.

Diplomacy may be detrimental to a functional health system when non-health sector policies and [international] agreements are negotiated with little or no attention to consider health related issues in the international system [27]. For example, the promotion of national economic interests, often done by the multinational corporations, can deprive the health sector of the actions needed, just as timely information can negatively impact quick action against the outbreak of any deadly virus. For example, the lack of timely information on the outbreak of Covid-19 that was declared as pandemic by WHO in March 2020 has left the entire world devastated as a result of its effects on the global economy.

Further to the above, health can be seen as a diplomatic tool to improve the relations between countries in varieties of ways, while conveying a far-reaching diplomatic message to improve a country's [possibly battered] image at home and abroad as [30, p. 274] asserts. In 2000 Cuba and Venezuela signed the Cuban medical diplomacy and the oil-for-doctors trade agreement to cement the two countries' diplomatic ties. Without mincing words, medical diplomacy has been the cornerstone of Cuban foreign policy since 1960. The country has provided medical assistance to scores of developing countries throughout the world both on a long-term basis and for short-term emergencies. For example, 60 Cuban medical doctors were in South Africa in 2020 to provide assistance while the latter was battling with the spread of the Covid-19 pandemic.

When a well-managed diplomatic relation incorporates and works towards realising the goals and the interests of health, a paradigm shift in the connection between diplomacy and global health takes place [23]. As earlier presented, this shift reflects the Oslo Ministerial Declaration (OMD), submitted by the foreign affairs of Brazil, France, Indonesia, Norway, Senegal, South Africa and Thailand in 2007, where it was declared, that the foreign policy of states should contribute to filling 
gaps and loopholes in international cooperation in health as well as the need to foster cooperation on issues, relating to health as a useful tool for diplomacy [22].

Given the above argument, it is pertinent to say that health plays a prominent role in global diplomacy, hence its contribution to human security. Essentially there are seven issues, associated with human security, these are economic security, food security, health security, environmental security, personal security, community security, and political security. More than other issues of security, health security is more complex. Srinivas (1994) opines that health security covers different issues, such as access to safe water, living in a safe environment, access to health services, access to safe and affordable family planning and basic support during pregnancy and delivery, prevention of HIV/AIDS and other diseases, and to have basic knowledge to live a healthy life.

Thus, acknowledging that severe and urgent threats to people could originate from sources, such as non-human, non-terrorist, or non-military security factors, distinguishes human security from traditional security paradigms [23]. Therefore, interventions globally are significantly important when a threat is simultaneous, prevalent by means of impacting several dimensions of human security and when states are incapacitated as a result of insufficient resources. The Covid-19 pandemic is a perfect example, as its existence is a threat to the existentiality of the human race. The international cooperation that follows the outbreak of the Covid-19 pandemic shows that the growing global interdependence among states is a challenge to the traditional perception of security and hence the need for a new concept of security that transcends the traditional security within the national boundaries, the security of individuals and communities beyond and across borders is promoted.

\section{2. Courting innovative diplomacy for health safety and security}

The adoption of the International Sanitary Regulations in 1851 and issues of international and global and health security have been on the international diplomatic agenda [31]. Thus, and diplomatically, both states and non-state-actors have increasingly engaged with one another in an attempt to put a stop or control the spread of dangerous and infectious diseases, such as cholera, HIV and AIDS, and non-communicable diseases. However, the Covid-19 virus appeared to be more dangerous than most of these diseases, hence the need for innovative diplomatic ideas to combat a universal virus, such as Covid-19. The Covid-19 pandemic, undeniably, constitutes the latest health security challenges that must be urgently and diplomatically addressed since the increase in migration and human movements through African porous borders, is a case while securing the health of both mobile and inactive populations.

Clearly, one nation's health status and risks can have impact not only on its own socio-economic prospects and those of its neighbours, but also those of the entire world. Good health is therefore, one of a liturgical prayer of global challenges. Meaning that while responses to such challenges require state action, they must be adequately addressed at the global level [31]. As opposed to merely inter-national, issues related to health must go beyond the state.

While the sources of the problems and potential solutions are situated at the transnational, regional or global level, the states still have the policy authority for confronting global problems, such as Covid-19 [32]. It is at this level that South Africa needs to put the following into consideration: Identify and collaborate with the global community to solve the problem, engage in the developing [local or international] innovative roadmap in response to the problem, and possible future occurrence of any virus.

In a democratic state like South Africa, policies and strategies that are developed to address health issues cum security often arise within the broad spectrum of political context. Debatably, the administration and policies in other sectors outside health, such as finance, state security, agriculture, trade, can have a significant effect on the outcome of health policies, just as actions, aimed at improving health security can affect other sectors [33]. Therefore, when health security issues transcend state's borders and become international, there is a possibility of having bilateral difficulties and challenges at both international organizations, such as the World Health Organisation (WHO), and in diplomatic negotiations. The reason for this is laid at the door step of the divergence of socio-economic and political interests among states, and between states and non-state actors. 
For example, in an attempt to address the barriers of control and regulation of the procurement, risks of becoming enmeshed in controversy over which state institutions should have how much authority over the procurement and distribution of Covid-19 vaccine, the South Africa's Department of Health at the national level is the sole purchaser of vaccines where it will be distributed to the provincial governments and the private sector. It therefore means that the decision to tackle the dangerous spread of Covid-19 must be influenced by the concern for national security, economic well-being, protection of human dignity, and by extension international health security development strategies. What this translates to mean is that for South Africa to achieve better understanding of the fight against the Covid-19, it requires South Africa's collaboration with the global health communities to achieve effective health policies.

One fact that needs to be stated is that diplomatic negotiations [at bilateral and multi-lateral levels] directly or indirectly affect health practices. In the context of aid-trade negotiations, the Trade-Related Aspects of Intellectual Property Rights (TRIPS) agreement introduced minimum standards for World Trade Organization (WTO) members to protect and enforce intellectual property rights and extended international standards to patent protection that was adopted by the WTO in 1995, it shows that non- strict health agreements at the international level can influence the diplomatic and health policy environment [34, p. 507]. What this portends to mean is that many developing nations [in Africa] may find it difficult to access Covid-19 vaccines on time, however, this could be mitigated particularly in Africa with the intervention of the African Union and through donors from the developed states.

As states incorporate health policies into their broader foreign policy strategies, there is a possibility that their local population health trepidations may be connected to the states' goals on health policies, thus creating the need for innovative ideas. It thus means that policy-makers vis-àvis health issues look up to the global health diplomacy as a means of accomplishing a variety of outcomes, from the aspirational to the purely realistic [34].

From the existentiality of threats, such as emerging transmissible disease like Covid-19, to underlying health risks amenable to global governance, the search for [local and international] interventions to reduce the wave of the Covid-19 in South Africa no doubt has put fresh pressures on its multilevel governance and on its core diplomacy, while trying to achieve its health objectives within the international legal frameworks.

It thus means that South Africa needs to start with emphasis on its readiness to diplomatically respond to health risks and threats to its health security. To do this, South Africa must innovatively engage the global mechanisms and other health security measures that will enable the former apartheid enclave to make an informed decision on its response to the Covid-19 pandemic. Further to this, South Africa of a necessity must identify critical gaps in its health system capacity, while trying to effectively implement its health policies side by side with the global health objectives with focus on national [and transnational] observation of diplomatic agreements on health, which may take various forms, such as a memorandum of understanding (MOU) or a cooperative agreement, based on its institutional culture and health program goals.

Understanding the importance of information and the effects of the crosscutting impacts of Covid-19 is pivotal to building on a commitment to fairness and mutual trust on the part of South Africa, while sharing information on the disease within the international community. This will enable states to identify the existing gaps, relating to the operation and implementation of health policies, such as safeguarding and guaranteeing convenience and accessibility of vaccines and medical equipment domestically as well as helping other countries that need assistance. Although South Africa may not have the financial capability to assist other countries to access vaccines and medical equipment to states in conflict and crisis, but providing information on the global outbreak alert will go a long way to help other countries, while trying to improve global health security.

Globally, the shortage of and inefficient and unfair distribution of trained health workers, particularly nurses and medical doctors [22, p. 1376] is seen as a major challenge to preparedness and to national and global health security. They concurred that the shortage of human resources is influenced by the global socio-economic system, incentives for migration and global negotiation on services. Such action they agreed goes beyond the health sector and can only be reformed through 
political actions [at the national, regional, and global level]. In response to this need, it is imperative for South Africa to train and employ more health workers, while encouraging regional and international exchanges at the academic institution level as well as strong innovative collaboration and partnerships through financial support for health research. South Africa can also facilitate better access for researchers from other countries within and outside Africa to innovative global knowledge networks. This will somewhat engender the possibility of instituting some multilateral/ bilateral mechanisms that would ensure the movement of health professionals and specialists alike with mutual benefit to the sending and receiving countries.

The saying that health is wealth is tantamount to saying that good and sustainable health is fundamental to socio-economic development as well as fighting poverty globally. Hunger is the ground, on which ill health breeds, and structurally, it is difficult to separate poverty from hunger, hence the need for workable policies to combat both structural and economic barriers to development and health challenges [22]. South Africa to some extent fits into the above state, looking at the [socio-economic] disparity between the haves and the have not in the former apartheid enclave. It does mean that South Africa must give health a top priority in its national development agenda.

South Africa can also push for innovative developmental cooperation models that are at par with its commitment to its national interests as well as strengthen the efficiency of its health initiatives through better-quality governance at the national, provincial and local level. As a regional power, it is imperative for South Africa to encourage the regional research capacity in the public health system, owing to the needs of the states in the region using a variety of innovative ideas, such as scientific exchange programmes, institutional collaborations, transfer of [medical] technology, etc., while fostering regional collaborations that is based on shared socio-economic and by extension political interests. This can be achieved by diplomatically promoting innovative ideas to boost the capacity for national and regional production of vaccines and equipment as well as promotion of national regulation of pharmaceuticals and commodities, quality control, and supply chain management

\section{Conclusion}

This paper has argued that for South Africa to be able to navigate through the Covid-19 pandemic, it is imperative for the Rainbow nation to ingratiate with innovative diplomacy, while ensuring its health safety and security amidst the Pandemic. It is on this ground that this paper concludes that it is imperative for South Africa to harness the current wave of innovation, to mitigate the disruptive effect of the pandemic on its socio-economic development.

South Africa's health security and economic development matters to South Africa [and Africa], this is because the rules of the game vis-à-vis health security determine the available space for policy-makers on socio-economic development at the national and by extension continental and regional level, which can be realised through innovative developmental cooperation models that is at par with its commitment to its national interests as well as strengthen the efficiency of its health initiatives through better-quality governance at the national, provincial and local level. In the increasingly globalised world, negotiations on safety and health security can be a leeway for South Africa [and Africa] to influence the rules of diplomatic game, while maximising its own health security space to enhance national health safety policies.

As stated above, a healthy nation is a wealthy nation, thus good and sustainable health is fundamental to South Africa's socio-economic development. South Africa must punch up its innovative developmental cooperation models with other states with focus on its commitment to its national interests, and also strengthen the efficiency of its health initiatives through better-quality governance at the national, provincial and local level. In a globalised system of innovation, South Africa cannot afford to be left behind, and as a continental/regional power South Africa need to see the innovation environment as a steady pipeline of its domestic ability to cut short the long-term negative socio-economic effect that the Covid-19 pandemic may likely have on its national health security.

Hence, the need for South Africa to begin to invest and localise the biotechnology industry. This has to do with the local adaption, indigenisation and modification of biotech industry. Apart 
from helping South Africa to boost the production of medical equipment, such as Testing Kits, Personal Protection Equipment (PPE) to manage the Covid-19 virus, it will also serve as a source of employment for teaming unemployed South Africans. For South Africa to achieve this, the uncertainty of the socio-economic and political environment must be attended to. Its rigid local labour markets, which have made it difficult for private [local and international] investors to participate and ensure the efficiency of health policy development, need to be relaxed if they must participate actively in state socio-economic activities that respond to the safety and health security of the emotionalized publics.

\section{Acknowledgments}

It is noteworthy to acknowledge the efforts and the encouragement of Dr Victor Mlambo who encouraged the author to put the work together.

\section{References}

[1] World Health Organisation (2020). Coronavirus disease 2019 (COVID-19) Situation Report - 57. Available at: https://www. who.int/docs/default-source/coronaviruse/situation-reports/20200317-sitrep-57-covid-19.pdf?sfvrsn=a26922f2_4

[2] Galal, S. (2021). Coronavirus cases in Africa as of June 9, 2021, by country. Available at: https://www.statista.com/statistics/1170463/coronavirus-cases-in-africa/

[3] Cook, N. (2020). South Africa: Current Issues, Economy, and U.S. Relations, Congressional Research Service. Available at: https://crsreports.congress.gov/product/pdf/R/R45687

[4] Lee, M., Lederer, E. M. (2020). Global diplomacy under the gun in the time of coronavirus. Associated Press. Available at: https:// apnews.com/article/understanding-the-outbreak-united-nations-virus-outbreak-international-news-united-nations-general-assembly-d61a53d19d262c3cf604cec6f4e52fad

[5] Adetiba, T. C. (2021). Reordering Diplomacy Amidst the Covid-19; Africa and the rest of the world. Journal of Social Political Sciences, 2 (2), 59-114.

[6] Ilona, K., Lister, G., Told, M., Drager, N. (Eds.) (2013). Global health diplomacy: Concepts, issues, actors, instruments, fora and cases. New York: Springer. doi: http://doi.org/10.1007/978-1-4614-5401-4

[7] ABC of Diplomacy. Bern: Swiss Federal Department of Foreign Affairs (FDFA) (2008). Federal Department of Foreign Affairs. Available at: https://www.eda.admin.ch/dam/eda/en/documents/publications/GlossarezurAussenpolitik/ABC-Diplomatie_en.pdf

[8] Kalvins, D. (2011). Understanding the Essence of Modern Diplomacy. Available at: http://www.culturaldiplomacy.org/ culturaldiplomacynews/participant-papers/2011-12-cdac/Understanding-the-Essence-of-Modern-Diplomacy-Didzis-Klavins.pdf

[9] Badie, B., Berg-Schlosser, D., Morlino, L. (Eds.) (2011). Diplomacy. International Encyclopedia of Political Science. London: Sage. Available at: https://sk.sagepub.com/reference/intlpoliticalscience/n153.xml

[10] Berridge, G. R. (2010). Diplomacy Theory and Practice. Basingstoke: Palgrave Macmillan.

[11] O'Gorman, G. (2015). The Effectiveness of Secrecy in Diplomacy. Oman: Sohar University. doi: http://oi.org/10.13140/ RG.2.2.25579.64800

[12] Berridge, G. R., Keens-Soper, M., Otte, T. G. (2001). Diplomatic Theory from Machiavelli to Kissinger. Basingstoke: Palgrave Macmillan. doi: http://doi.org/10.1057/9780230508309

[13] Bound, K., Saunders, T., Wilsdon, J., Adams, J. (2013). China's Absorptive State: Research, Innovation and the Prospects for China-UK Collaboration. London: Nesta.

[14] Matambo, E. (2020). International Relations Theory after the Cold War: China, the Global South and Non-State Actors. Available at: https://www.e-ir.info/2020/04/21/international-relations-theory-after-the-cold-war-china-the-global-south-andnon-state-actors/

[15] Griset, P. (2020). Innovation Diplomacy: A New Concept for Ancient Practices? The Hague Journal of Diplomacy, 15 (3), 383-397. doi: http://doi.org/10.1163/1871191x-bja10036

[16] Leijten, J. (2017). Exploring the future of innovation diplomacy. European Journal of Futures Research, 5 (20), 1-13. doi: http:// doi.org/10.1007/s40309-017-0122-8

[17] The Royal Society and AAAS (2010). New frontiers in science diplomacy; Navigating the changing balance of power Science Policy Centre. Londonб 32.

[18] Kahn, E. (2007). Innovate or Perish: Managing the Enduring Technology Company in the Global Market. New Jersey: Wiley, 336.

[19] Breznitz, D., Murphree, M.; Breznitz, D., Zysman, J. (Eds.) (2013). China’s Run: Economic Growth, Policy, Interdependences, and Implications for Diverse Innovation Policies in a World of Fragmented Production. The Third Globalization: Can 
Wealthy Nations Stay Rich in the Twenty-First Century? Oxford and New York: Oxford University Press, 35-36. doi: http:// doi.org/10.1093/acprof:oso/9780199917822.003.0003

[20] Weisbrode, K. (2017). Diplomacy in Foreign Policy. Oxford Research Encyclopedias. doi: http://doi.org/10.1093/acrefore/9780190228637.013.410

[21] Labonté, R., Gagnon, M. L. (2010). Framing health and foreign policy: lessons for global health diplomacy. Globalization and Health, 6 (1), 14. doi: http://doi.org/10.1186/1744-8603-6-14

[22] Oslo Ministerial Declaration - global health: a pressing foreign policy issue of our time (2007). The Lancet, 369 (9570), 1373-1378. doi: http://doi.org/10.1016/s0140-6736(07)60498-x

[23] Chattu, V. K., Knight, A. W., Kevany, S., Sehovic, A. B. (2019). Global health diplomacy, health and human security: The ascendancy of enlightened self-interest. Journal of Education and Health Promotion, 8 (107).

[24] Kickbusch, I, (2013). Twenty- First Century Health Diplomacy. London: Imperial College, World Scientific.

[25] National armies for global health? (2014). The Lancet, 384 (9953), 1477. doi: http://doi.org/10.1016/s0140-6736(14)61923-1

[26] Buekens, P. (2013). Medical school deans' letter to President Obama. http://www.jhsph.edu/news/newsreleases/2013/Klag\%20 letter $\% 20$ to $\% 20$ President $\% 20$ Obama.pdf

[27] Kickbusch, I., Lister, G., Told, M., Drager, N. (Eds.) (2013). Global Health Diplomacy: Concepts, Issues, Actors, Instruments, Fora and Cases. New York: Springer.

[28] Michaud, J., Kates, J. (2012). Raising the Profile of Diplomacy in the U.S. Global Health Response: A Backgrounder on Global Health Diplomacy. Menlo Park: Kaiser Family Foundation.

[29] Shah, R., Goosby, E., Frieden, T., Quam, L. (2012). Global Health Initiative Next Steps - A Joint Message. Washington: U.S. Global Health Initiative.

[30] Feinsilver, J. M. (2008). Oil-for-doctors: Cuban medical diplomacy gets a little help from a Venezuelan friend. Nueva Soc. Available at: http://nuso.org/media/articles/downloads/3537_2.pdf

[31] Šehović, A. B (2017). Securing Global Health through Diplomacy: From One-Way Transfer to Multi-Directional Knowledge Exchange. Policy paper No 2, Institute for European Studies.

[32] Berry, F. S., Berry, W. D.; Sabatier, P. A. (Ed.) (1999). Innovation and diffusion models in policy research. Theories of the policy process. Boulder: Westview Press.

[33] Heymann, D. L., Chand, S.; Kickbusch, I., Lister ,G., Told, M., Drager, N. (Eds.) (2013). Diplomacy and Global Health Security. In Global Health Diplomacy. New York: Springer, 125-139. doi: http://doi.org/10.1007/978-1-4614-5401-4_9

[34] Katz, R., Kornblet, S., Arnold, G., Lief, E., Fisher, J. E. (2011). Defining Health Diplomacy: Changing Demands in the Era of Globalization. The Milbank Quarterly, 89 (3), 503-523. doi: http://doi.org/10.1111/j.1468-0009.2011.00637.x

Received date 19.09.2021

(C) The Author(s) 2021

Accepted date 24.11.2021

This is an open access article under the

Published date 30.11.2021

Creative Commons CC BY license

How to cite: Adetiba, T. C. (2021). Courting innovative diplomacy for health safety and security amidst the Covid-19 pandemic; the case of South Africa. EUREKA: Social and Humanities, 6, 31-42. doi: http://doi.org/10.21303/2504-5571.2021.002068 